\title{
MOTIVASI KERJA DAN KEPUASAN KERJA TERHADAP KINERJA KARYAWAN (Studi pada karyawan PT. Bank Negara Indonesia (Persero)Tbk Cabang Karawang)
}

\author{
Dra. Sari Marliani, MM \\ Universitas Buana Perjuangan Karawang \\ e-mail: 1 Sari.marliani@ubpkarawang.ac.id
}

\begin{abstract}
This study aims to determine the influence of job satisfaction, work motivation to employee performance. Using by simple random sampling method 40 respondents from taken 160 employees population. Explanatory research use SPSS 20, the data used is primary and secondary data, . The analysis showed that: the relationships among the exogenous variables of job satisfaction and work motivation has a direct influence on the endogenous variable employee performance. Therefore, it is still necessary to improve the performance of an increase in motivation, job satisfaction to employees by providing stimuli.
\end{abstract}

Keyword: Work Motivation, Job Satisfaction, and Employee Performance.

\begin{abstract}
Abstrak
Penelitian ini bertujuan untuk mengetahui seberapa besar pengaruh motivasi kerja dan kepuasan kerja kerja terhadap kinerja karyawan . Pengambilan sampel dilakukan dengan metode simple random sampling 40 orang responden dari populasi yang berjumlah 160 orang karyawan. Dalam penelitian ini menggunakan SPSS 20, data yang digunakan yaitu data primer dan sekunder, Hasil analisis menunjukkan bahwa : variabel eksogen kepuasan kerja dan motivasi kerja terdapat pengaruh terhadap variabel endogen kinerja karyawan. Oleh karena itu untuk meningkatkan kinerja masih diperlukan adanya peningkatan motivasi, kepuasan kerja dengan memberikan stimuli kepada karyawan.
\end{abstract}

Kata Kunci: Motivasi Kerja, Kepuasan Kerja, dan Kinerja Karyawan 


\section{BAB I \\ PENDAHULUAN}

\subsection{Latar Belakang}

Persaingan dalam dunia bisnis perbankan dewasa ini sangat ketat sekali, terutama di era globalisasi dan MEA yang semakin meluas di berbagai penjuru dunia. Dengan banyaknya bank-bank swasta bermunculan baik dari dalam negri maupun dari luar yang ikut meramaikan peta persaingan yang tumbuh dan berkembang secara dinamis dalam hal pelayanan yang prima terhadap nasabah dalam mengantisipasi kebutuhan dan layanan untuk kepuasan nasabah.

Untuk dapat bersaing dengan perusahaan lain yang sejenis perusahaan harus mempunyai keunggulan yang kompetitif yang sulit ditiru, yang hanya akan diperoleh dari karyawan yang produktif, inovatif, kreatif selalu bersemangat dan loyal . Karyawan yang memenuhi kriteria seperti itu hanya akan dimiliki melalui penerapan konsep dan tekhnik manajemen sumber daya manusia yang tepat dengan semangat kerja yang tinggi serta pemimpin yang efektif dan lingkungan kerja yang mendukung, faktor-faktor yang dapat digunakan untuk meningkatkan kinerja pegawai , diantaranya motivasi dan kepuasan kerja.

Setiap individu harus mempunyai kekuatan dorongan diri untuk mau berubah dalam dirinya sendiri, kekuatan pendorong inilah yang disebut motivasi. Motivasi kerja karyawan dalam suatu organisasi dapat dianggap sederhana dan dapat pula menjadi masalah yang kompleks, karena pada dasarnya manusia mudah untuk dimotivasi dengan memberikan apa yang menjadi keinginannya. Motivasi bisa timbul dari dua faktor yaitu : faktor intrinsik (faktor yang timbul dari dalam) yaitu faktor motivasi yang timbul dari dalam individu tersebut. Sebagai indikator dalam faktor tersebut adalah adanya keinginan untuk berprestasi dan mengembangkan kualitas kehidupan pribadinya sedangkan faktor eksintrik, yaitu faktor yang berasal dari luar individu tersebut yang akan mempengaruhinya dalam bekerja. Sebagai indikator faktor eksintrik yaitu jenis pekerjaan itu sendiri, status kerja, tempat pekerjaan, keamanan pekerjaan, penghasilan yang layak, pengakuan dan penghargaan kepercayaan dalam melakukan pekerjaan, kepemimpinan yang baik, adil dan kebijaksanaan administrasi. 
Menciptakan kepuasan kerja karyawan adalah tidak mudah karena kepuasan kerja dapat tercipta jika variabel-variabel yang mempengaruhinya antara lain motivasi kerja, yang dapat diakomodasikan dengan baik dan diterima oleh semua karyawan di dalam suatu organisasi/perusahaan. Kinerja organisasi tergantung dari kinerja individu atau dengan kata lain kinerja individu akan memberikan kontribusi pada kinerja organisasi, artinya bahwa perilaku anggota organisasi baik secara individu maupun kelompok memberikan kekuatan atas kinerja organisasi sebab motivasinya akan mempengaruhi pada kinerja organisasi.

Kinerja adalah pencapaian atas tujuan organisasi yang dapat berbentuk output kuantitatif maupun kualitatif, kreatifitas, fleksibilitas, dapat diandalkan, atau hal-hal lain yang diinginkan oleh organisasi. Penekanan kinerja dapat bersifat jangka pendek maupun jangka panjang, juga dapat pada tingkatan individu, kelompok ataupun organisasi.

Manajemen kinerja merupakan suatu proses yang dirancang untuk menghubungkan tujuan organisasi dengan tujuan individu, sehingga kedua tujuan tersebut bertemu. Kinerja juga dapat merupakan tindakan atau pelaksanaan tugas yang telah diselesaikan oleh sesorang dalam kurun waktu tertentu dan dapat diukur. Ada 4 (empat) unsur-unsur yang terdapat dalam kinerja adalah hasil-hasil fungsi pekerjaan, faktor-faktor yang berpengaruh terhadap prestasi karyawan, pencapaian tujuan organisasi, dan periode waktu tertentu.

\subsection{Rumusan Masalah}

Dalam mencapai hasil yang diharapkan oleh perusahaan dalam menghadapi hambatan yang di perkirakan maka dapat dirumuskan masalah sebagai berikut :

1.2.1 Apakah terdapat pengaruh motivasi kerja terhadap kinerja karyawan ?

1.2.2 Apakah terdapat pengaruh kepuasan kerja karyawan terhadap kinerja karyawan ?

1.2.3 Apakah terdapat pengaruh motivasi kerja dan kepuasan kerja karyawan secara bersama-sama terhadap kinerja karyawan?

\subsection{Tujuan Penulisan}

Pembuatan makalah ini bertujuan untuk mengetahui secara empiris hubungan antara motivasi kerja dan kepuasan kerja dengan kinerja , secara khusus , tujuan makalah ini adalah sebgai berikut :

1.3.1 Untuk mengetahui pengaruh motivasi kerja terhadap kepuasan karyawan ?

1.3.2 Untuk mengetahui pengaruh kepuasan kerja karyawan terhadap kinerja karyawan? 
1.3.3 Untuk mengetahui pengaruh motivasi kerja dan kepuasan kerja karyawan secara bersama-sama terhadap kinerja karyawan?

\subsection{Manfaat Penulisan}

Hasil pembuatan makalah ini diharapkan dapat memberikan manfaat baik secara teoritis, maupun praktis. Secara teoritis hasil penelitian ini diharapkan manfaatnya bagi :

\subsubsection{Bagi Penulis}

makalah ini diharapkan berguna dalam menambah ilmu pengetahuan khususnya dalam bidang MSDM

\subsubsection{Bagi Perusahaan}

Diharapkan dari makalah ini dapat memberikan kontribusi pmikiran yang bermanfaat dan sebagai bahan pertimbahgan dalam pngambilan keputusanbagi perusahaan, agar dapat menghasilkan sumber daya yang berkualitas.

\subsubsection{Bagi Akademis}

Dari makalah ini penulis lakukan diharapkan dapat berguna sebagai bahan bacaan untuk melengkapi perpustakaan fakltas dan dapat berguna sebagai bahan referensi dan perbandingan bagi pembaca.

\subsubsection{Bagi Masyarakat}

Dalam makalah ini diharapkan dapat berguna bagi masyarakat dan mampu sebagai tolak ukur bagi masyarakat untuk dijadikan sebagai referensi sehingga menjadi acuan dan menjadi loyalitas kepada perusahaan

\subsection{Metode Penelitian}

Metode yang digunakan dalam penelitian ini :

\subsubsection{Populasi}

Populasi adalah wilayah generalisasi yang terdiri atas abyek/subyek yang mempunyai kualitas dan karakteristik tertentu yang ditetapkan oleh peneliti untuk dipelaari dan kemudian ditarik kesimpulan (Sugiyono, 1999). Populasi penelitian ini adalah seluruh karyawan tetap yang berjumlah 160 orang. 


\subsubsection{Sampel}

Sampel adalah bagian atau wakil populasi yang diteliti, sampel merupakan sebagian dari populasi yangmmiliki karakteristik yang relative sama dan dianggap bisa mewakili populasi (sugiono, 1999).

Metode pengambilan sampel yang tepat agar diperoleh sampel yang representative dan dapat mengambarkan keadaan populasi secara maksimal, smpel yang diambil sebesar 25\% (Suharsini Arikunto, 1998 ; 11). Maka dari 160 orang populasi maka diambil sampel sebesar 25\% berjumlah 40 orang karyawan.

\subsubsection{Teknik Pemgambilan Sampel}

Teknik pengambilan sampel yang digunakan dalam penelitian ini adalah proposional sampling dengan menggunakan metode stratified random sampling yaitu : a) Stratified (Strata/tingkatan) untuk menentukan klasifikasi jabatan , b) proposional random sampling untuk menentukan jumlah sampelnya.

1.5.4. Jenis dan Sumber data dan metode pengumpulan data

- Jenis data yang digunakan dalam penelitian ini adalah :

\subsubsection{Data Primer}

Data primer merupaka data yang dikumpulkan sendiri oleh perorangan atau langsung melalui objeknya. Pengumpulan data ini biasanya dilakukan dengan membagikan kuesioner kepada objek penelitian dan di isi langsung yang responden.

\subsubsection{Data Sekunder}

Data sekunder adalah data yang diperoleh secara tidak langsung atau melalui media perantara. Data yang didapatkan dari arsip yang dimiliki organisasi, studi pustaka, penelitian terdahulu, literature dan jurnal yang berhubungan dengan permasalahn yang diteliti.

\subsubsection{Metode pengumpulan Data}

\subsection{Wawancara}

\subsection{Kuesioner}

\subsection{Teknik Skala}

\subsubsection{Teknis Analisis Data}

Analisis data merupakan suatu proses penyederhanaan data ke dalam bentuk yang lebih mudah dibaca dan diinterprestasikan. Degan menggunakan metode kuantitatif, diharapkan akan mendapatkan hasil pengukuran yang lebih akurat. Dengan model regresi dapat dilakukan beberapa pengujian statistic, yaitu dengan : 
1.5.5.1. Uji T

1.5.5.2. UJI F

1.5.5.3. Koefissien Determinasi

1.5.5.4. Uji validitas

1.5.5.5. Uji reabilitas

1.5.5.6. Teknik pengujian hipotesis 


\section{BAB II \\ PERMASALAHAN DAN TEORI}

Permasalahan yang terjadi di PT. Bank Negara Indonesia (Persero)Tbk Cabang Karawang banyak pekerjaan yang dilakukan tidak sesuai dengan apa yang diperoleh dari perusahaan. Ketidakpuasan para karyawan ini menimbulkan hal-hal yang tidak diinginkan dan dapat merugikan perusahaan misalnya ; adanya banyak melakukan kesalahan, kemangkiran karyawan meningkat, turunnya kinerja karyawan, sering tidak masuk kerja, mengabaikan perintah atasan dan lain-lain, yang pada akhirnya akan menurunkan kinerja perusahaan itu sendiri. Maka, para pimpinan sebaiknya mengerti apa yang dibutuhkan para karyawan dan mengetahui keinginan-keinginan apa yang membuat karyawan puas dan meningkatnya kinerjanya, berikut semua konsekuensinya, termasuk apa dan berapa bonus yang akan mereka terima jika target atau tujuan kerjanya tercapai, sehingga para karyawan tidak melakukan halhal yang tidak sepantasnya dikerjakan.

Ketidakpuasan yang dirasakan oleh karyawan saat ini di PT. Bank Negara Indonesia (Persero)Tbk Cabang Karawang dari banyaknya karyawan yang sering bolos, tidak disiplin dalam absensi, tidak diperlakukan baik oleh atasan, kenaikan pangkat yang ditunda, peraturan yang sering berubah-ubah, sering membuat kesalahan, maka tingkat kepuasan karyawan dalam bekerja rendah, karena karyawan merasa tidak nyaman bekerja di perusahaan. Tinginya jumlah karyawan yang merasa tidak nyaman di perusahaan juga dapat disebabkan oleh kebijakan perusahaan yang selalu berubah-ubah sehingga membuat karyawan menjadi binggung dalam menjalankan perintah pimpinan.

Akibatnya proses pekerjaan tidak berjalan seperti biasanya dan akan berdampak pada pelayanan kepada nasabah bank, contohnya petugas teller dan customer service yang seharusnya menyapa dengan ramah, senyum dan sopan akan berubah menjadi tidak ramah, dan tidak memberikan pelayanan yang maksimal terhadap nasabah dan nasabah tidak merasa puas dengan perlakuan dari petugas bank tersebut, yang seharusnya baik akan berakibat buruk karena kinerja petugas teller dan customer service menurun yang disebabkan motivasi dan tingkat kepuasan karyawan menurun. 
Memang tidak mudah memuaskan karyawan karena kepuasan kerja merupakan hal yang bersifat individual. Setiap individu akan memiliki tingkat kepuasan yang berbeda-beda dalam dirinya. Hal ini sesuai dengan pengertian kepuasan itu sendiri, dimana kepuasan kerja merupakan keadaan emosional yang menyenangkan maupun tidak menyenangkan dimana para karyawan memandang pekerjaannya. Hal ini nampak pada sikap karyawan terhadap pekerjaannya, sikap positif bila puas atau sikap negatif bila tidak puas.

Ketidakpuasan karyawan dapat dinyatakan dalam berbagai cara. Misalnya, berhenti bekerja, karyawan mengeluh, tidak patuh, atau mengelakkan sebagian dari tanggung jawab kerjanya. Sementara kepuasan kerja merupakan salah satu tujuan yang ingin dicapai oleh setiap karyawan di tempat kerjanya. Adanya karyawan yang puas membuat moral kerja, dedikasi, kecintaan, dan kedisiplinan karyawan meningkat. Untuk itu sudah menjadi keharusan bagi perusahaan untuk menciptakan kepuasan kerja para karyawannya.

\subsection{Pengertian Motivasi Kerja}

\subsubsection{Teori Abraham H. Maslow (Teori Kebutuhan) (Winardi, 2001:69-93)}

Teori motivasi yang dikembangkan oleh Abraham H. Maslow pada intinya berkisar pada pendapat bahwa manusia mempunyai lima tingkat atau hierarki kebutuhan, yaitu : a) Kebutuhan fisiologikal (physiological needs), seperti : rasa lapar, haus, istirahat dan sex; b) Kebutuhan rasa aman (safety needs), tidak dalam arti fisik semata, akan tetapi juga mental, psikologikal dan intelektual ; c) Kebutuhan akan kasih saying (love needs); d) Kebutuhan akan harga diri (esteem needs), yang pada umumnya tercermin dalam berbagai symbol-simbol status ; e) Aktualisasi diri (self actualization), dalam arti tersedianya kesempatan bagi seseorang untuk mengembangkan potensi yang terdapat dalam dirinya sehingga berubah menjadi kemampuan nyata.

\subsubsection{Teori McClelland (Winardi, 2001:69-93)}

Menurut McClelland karakteristik orang yang berprestasi tinggi (high achievers) memiliki tiga ciri umum yaitu : a) Sebuah preferensi untuk mengerjakan tugas-tugas dengan derajat kesulitan moderat, ; b) Menyukai situasi-situasi dimana kinerja mereka timbul karena upaya -upaya mereka sendiri, dan bukan karena faktor-faktor lain, seperti kemujuran ; c) Menginginkan umpan balik tentang keberhasilan dan kegagalan mereka, dibandingkan dengan mereka yang berprestasi rendah. 


\subsubsection{Teori Clyton Alderfer (Teori “ERG”) (Winardi, 2001:69-93)}

Teori Alderfer dikenal dengan akronim "ERG". Akronim "ERG" dalam teori Alderfer merupakan huruf-huruf pertama dari tiga istilah yaitu : $\mathrm{E}=$ Existence (kebutuhan akan eksistensi), $\mathrm{R}=$ Relatedness (kebutuhan untuk berhubungan dengan pihak lain, dan $\mathrm{G}=$ Growth (kebutuhan akan pertumbuhan).

\subsubsection{Teori Herzberg (Winardi, 2001:69-93)}

Ilmuwan ketiga yang diakui telah memberikan kontribusi penting dalam pemahaman motivasi Herzberg. Teori yang dikembangkannya dikenal dengan "Model Dua Faktor" dari motivasi, yaitu faktor motivasional dan faktor hygiene atau "pemeliharaan".

Menurut teori ini yang dimaksud faktor motivasional adalah hal-hal yang mendorong berprestasi yang sifatnya intrinsik, yang berarti bersumber dalam diri seseorang, sedangkan yang dimaksud dengan faktor hygiene atau pemeliharaan adalah faktor-faktor yang sifatnya eksintrik yang berarti bersumber dari luar diri yang turut menentukan perilaku seseorang dalam kehidupan seseorang.

\subsubsection{Teori Keadilan (Winardi, 2001:69-93)}

Inti teori ini terletak pada pandangan bahwa manusia terdorong untuk menghilangkan kesenjangan antara usaha yang dibuat bagi kepentingan organisasi dengan imbalan yang diterima. Artinya , apabila seorang pegawai mempunyai persepsi bahwa imbalan yang diterimanya tidak memadai, dua kemungkinan dapat terjadi, yaitu : a) seorang akan berusaha memperoleh imbalan yang lebih besar ; b) mengurangi intensitas usaha yang dibuat dalam melaksanakan tugas yang menjadi tanggung jawab.

\subsubsection{Teori Penetapan Tujuan (goal setting theory)}

Edwin Locke mengemukakan bahwa dalam penetapan tujuan memiliki empat macam mekanisme motivasional yakni : a) tujuan-tujuan mengarahkan perhatian ; b) tujuan-tujuan mengatur upaya ; c) tujuan-tujuan meningkatkan persistensi ; d) tujuantujuan menunjang strategi-strategi dan rencana-rencana kegiatan.

\subsubsection{Teori Victor H. Vroom (Winardi, 2001:69-93)}

Victor H. Vroom, dalam bukunya yang berjudul "Work and Motivation" mengetengahkan suatu teori yang disebutnya sebagai "Teori Harapan”. Menurut teori ini, motivasi merupakan akibat suatu hasil dari yang ingin dicapai oleh seorang dan perkiraan yang bersangkutan bahwa tindakannya akan mengarah kepada hasil yang 
diinginkannya itu. Artinya, apabila seseorang sangat menginginkan sesuatu, dan jalan tampaknya terbuka untuk memperolehnya, yang bersangkutan akan berupaya mendapatkannya.

\subsubsection{Teori Penguatan dan Modifikasi Perilaku (Winardi, 2001:69-93)}

Dalam hal ini berlakulah apa yang dikenal dengan "hukum pengaruh" yang menyatakan bahwa manusia cenderung untuk mengulangi perilaku yang mempunyai konsekuensi yang menguntungkan dirinya dan mengelakkan perilaku yang mengakibatkan perilaku yang mengakibatkan timbulnya konsekuensi yang merugikan.

Penting untuk diperhatikan bahwa agar cara-cara yang digunakan untuk modifikasi perilaku tetap memperhitungkan harkat dan martabat manusia yang harus selalu diakui dan dihormati, cara-cara tersebut ditempuh dengan "gaya" yang manusiawi pula.

\subsubsection{Teori Kaitan Imbalan dengan Prestasi}

Menurut model ini motivasi seorang individu sangat dipengaruhi oleh berbagai factor , baik yang bersifat internal adalah : a) persepsi seseorang mengenai diri sendiri; b) harga diri; c) harapan pribadi; d) kebutuhan; e) keinginan; f) kepuasan kerja; g) prestasi kerja yang dihasilkan.

Sedangkan factor eksternal mempengaruhi motivasi seseorang, antara lain ialah : a) jenis dan sifat pekerjaan ; b) kelompok kerja dimana seseorang bergabung ; c) organisasi tempat bekerja ; d) situasi lingkungan pada umumnya; e) sistem imbalan yang berlaku dan cara penerapannya. (Winardi, 2001:69-93;Sondang P. Siagian, 286-294; Indriyo Gitosudarmo dan Agus Mulyono, 183-190, Fred luthan, 140-167).

\subsection{Teori Motivasi Douglas McGregor}

Mengemukakan dua pandangan manusia yaitu teori X (negative) dan teori $\mathrm{Y}$ (positif), Menurut teori $\mathrm{X}$ empat pengandaian yang dipegang pimpinan, yaitu : a) Pegawai secara inheren tertanam dalam dirinya tidak menyukai kerja, b) Pegawai tidak menyukai kerja mereka harus diawasi atau diancam dengan hukuman untuk mencapai tujuan, c) Pegawai akan menghindari tanggung jawab, d) kebanyakan oegawai menaruh keamanan diatas semua factor yang dikaitkan dengan kerja .

Kontras dengan pandangan negative ini mngenai kodrat manusia ada empat teori $\mathrm{Y}$; a) Pegawai dapat memandang kerjasama dengan sewajarnya seperti istirahat dan bermain, b) orang akan menjalankan pengarahan diri dan pengawasan diri jika mereka komit pada sasaran, c) ratarata orang akan menerima tanggung jawab, d) kemampuan untuk mengambil keputusan inovatif.

Dari uraian diatas dapat kita garis bawahi motivasi meupakan suatu faktor yang mendorong seseorang untuk melakukan suatu aktivitas tertentu atau bisa kita artikan pula bahwa 
motivasi adalah faktor pendorong atas perilaku seseorang untuk mencapai tujuan, tentu saja hal ini bersifat berbeda antara satu individu dengan individu yang lain.

\subsection{Teknik Memotivasi Kerja}

Mangkunegara (2005:101) mengemukakan bahwa terdapat 2 (dua) teknik memotivasi kerja yaitu : a) Teknik pemenuhan kebutuhan pegawai , artinya bahwa pemenuhan kebutuhan pegawai merupakan fundamen yang mendasar perilaku kerja. b) Teknik komunikasi persuasive adalah merupakan salah satu teknik memotivasi kerja pegawai yang dilakukan dengan cara mempengaruhi pegawai secara ekstra logis.

Teknik ini dirumuskan dengan istilah "AIDDAS” yaitu Attention (perhatian), Interest (Minat), Desire (Hasrat), Action (Aksi atau tindakan), dan Satisfaction (kepuasan).

\subsection{Pengertian Kepuasan Kerja.}

Kepuasan kerja adalah keadaan emosional yang menyenangkan atau tidak menyenangkan dimana para karyawan memandang pekerjaan mereka. Kepuasan kerja mencerminkan perasaan seseorang terhadap pekerjaannya, kepuasan kerja ini nampak dalam sikap positif karyawan terhadap pekerjaan dan segala sesuatu yang dihadapi di lingkungan kerjanya. (Handoko, 1996).

Selain itu kepuasan kerja juga dapat diartikan sebagai sebuah efektivitas atau respon emosional terhadap berbagai aspek pekerjaan (Kreiner : 2005). Keadaan emosional yang menyenangkan atau tidak menyenangkan dengan mana para pekerja memandang pekerjaan mereka (Handoko : 1996). Kepuasan kerja merupakan sebuah cara untuk mengaktualisasikan diri, sehingga akan tercapai sebuah kematangan psikologis pada diri karyawan, jika kepuasan tidak tercapai , maka dapat terjadi kemungkinan karyawan akan frustasi (Strauss dan Sayles dalam Handoko, 1996).

Kepuasan kerja adalah perilaku individual terhadap pekerjaannya. Organisasi yang karyawannya mendapatkan kepuasan mendapatkan kepuasan di tempat kerja maka cenderung lebih efektif daripada organisasi yang karyawannya kurang mendapatkan kepuasan kerja (Robbins, 2001).

Dari definisi tersebut dapat diartikan bahwa kepuasan kerja adalah suatu respon yang mengambarkan perasaan dari individu terhadap pekerjaannya. Kepuasan kerja adalah kombinasi dari kepuasan kognitif dan efektif individu dalam perusahaan. Kepuasan efektif didapatkan dari seluruh penilaaian emosional yang positif dari pekerjaan karyawan. 
kepuasan afektif ini difokuskan pada suasana hati mereka saat mereka bekerja. Perasaan positif atau suasana hati yang positif mengindikasikan kepuasan kerja. Sedangkan kepuasan kerja kognitif adalah kepuasan yang didapatkan dari penilaian logi dan rasional terhadap kondisi, peluang dan atau "Out come".

Locke dalam Luthan (2006) memberikan definisi komprehensif dari kepuasan kerja yang meliputi reaksi atau sikap kognitif, afektif dan evaluative dan menyatakan bahwa kepuasan kerja adalah " keadaan emosi yang senang atau emosi positif yang berasal dari penilaian pekerjaan atau pengalaman kerja seseorang". Kepuasan kerja adalah hasil dari persepsi karyawan mengenai seberapa baik pekerjaan mereka memberikan hal yang dinilai penting, secara umum kepuasan kerja adaah sikap yang paling penting dan sering dipelajari.

Dari definisi tersebut dapat diartikan bahwa kepuasan kerja adalah perasaan emosi yang menyenangkan atau positif yang dihasilkan dari penilaian kerja seseorang atau pengalaman kerja. Terdapat tiga dimensi penting dalam kepuasan kerja,

1. Kepuasan adalah respon emosional dari situasi kerja.

2. Kepuasan kerja seberapa hasil yang didapatkan atau apakah hasil yang diperoleh sesuai dengan harapan.

3. Kepuasan kerja menggambarkan pula perilaku.

\subsubsection{Faktor-Faktor yang mempengaruhi kepuasan kerja.}

Teori-teori kepuasan kerja menurut Mangkunegara (2000) antara lain :

\subsubsection{Teori Keseimbangan (Equity Theory)}

Teori ini dikembangkan oleh Adam. Adapun komponen dari teori ini adalah input, outcome, comparison person, dan equity-in-equity. Input adalah semua nilai yang diterima karyawan yang dapat menunjang pelaksanaan kerja. misalnya pendidikan, pengalaman, skill, usaha, peralatan pribadi dan jumlah jam kerja.

\subsubsection{Teori Perbedaan (Discrepancy Theory)}

Teori ini pertama kali dipelopori oleh Porter. Ia berpendapat bahwa mengukur kepuasan dapat dilakukan dengan cara menghitung selisih antara apa yang seharusnya dengan kenyataan yang dirasakan karyawan. Locke mengemukakan bahwa kepuasan kerja karyawan tergantung pada perbedaan antara apa yang didapt dan apa yang diharapkan oleh karyawan. Apabila yang didapat 
karyawan ternyata lebih besar daripada apa yang diharapkan maka karyawan tersebut menjadi puas. Sebaliknya, apabila yang didapat karyawan lebih rendah daripada yang diharapkan, akan menyebabkan karyawan tidak puas.

\subsubsection{Teori Pemenuhan Kebutuhan (Need Fulfillment Theory)}

Teori ini pertama kali dipelopori A. H. Maslow. dikemukakan oleh A. H. Maslow tahun 1943. Teori ini merupakan kelanjutan dari "Human Science Theory" Elton Mayo (1880-1949) yang menyatakan bahwa kebutuhan dan kepuasan seseorang itu jamak, yaitu kebutuhan biologis dan psikologis berupa kebutuhan materiil dan non-materiil.

\subsubsection{Teori Pandangan Kelompok (Social Reference Group Theory)}

Menurut teori ini, kepuasan kerja karyawan bukanlah bergantung pada pemenuhan kebutuhan saja, tetapi sangat bergantung pada pandangan dan pendapat kelompok yang oleh para karyawan dianggap sebagai kelompok acuan. Kelompok acuan tersebut oleh karyawan dijadikan tolak ukur untuk menilai dirinya maupun lingkungannya. Jadi karyawan akan merasa puas apabila hasil kerjanya sesuai dengan minat dan kebutuhan yang diharapkan oleh kelompo acuan.

\subsubsection{Teori Pengharapan (Ecpentancy Theory)}

Teori pengharapan dikembangkan oleh Victor H. Vroom. Kemudian teori ini diperluas oleh Porter dan Lawyer. Vroom menjelaskan bahwa motivasi suatu produk dari bagaimana seseorang menginginkan sesuatu dan penaksiran seseorang memungkinkan aksi tertentu yang akan menuntunnya.

\subsubsection{Teori Dua Faktor Herzberg (Herzberg's Two Factor Theory)}

Dua faktor yang dapat menyebabkan timbulnya rasa puas atau tidak puas menurut Herzberg, yaitu faktor pemeliharaan (maintenance factors) dan factor pemotivasian (motivational factors). Factor pemeliharaan disebut pula dissatisfiers, hygiene factors, job context, extrinsic factors yang meliputi administrasi dan kebijakan perusahaan, kualitas pengawasan, hubungan dengan pengawas, hubungan dengan sub ordinat, upah, keamanan kerja, kondisi kerja dan status . sedangkan faktor pemotivasian disebut pula satisfier, motivators, job, content, intrinsic factor yang meliputi dorongan berprestasi, pengenalan, kemajuan (advancement), kesempatan berkembang dan tanggung jawab. 
Ada lima faktor penentu kepuasan kerja yang disebut dengan Job Descriptive Index (JDI) (Luthans dan Spector dalam Robins 2006), yaitu :

1) Pekerjaan itu sendiri

Tingkat dimana sebuah pekerjaan menyediakan tugas yang menyenangkan, kesempatan belajar dan kesempatan untuk mendapatkan tanggung jawab. Hal ini menjadi sumber mayoritas kepuasan kerja.

Menurut Locke, ciri-ciri intrinsic yang menentukan kepuasan kerja adalah keragaman, kesulitan, jumlah pekerjaan, tanggung jawab, otonomi, kendali terhadap metode kerja, kemajemukan dan kreativitas.

\section{2) Gaji}

Menurut penelitian Theriault, kepuasan kerja merupakan fungsi dari jumlah absolute dari gaji yang diterima, derajad sejauh mana gaji memnuhi harapanharapan tenaga kerja, dan bagaimana gaji diberikan, upah dan gaji diakui merupakan faktor yang signifikan terhadap kepuasan kerja.

3) Kesempatan atau promosi

Karyawan memiliki kesempatan untuk mengembangkan diri dan memperluas pengalaman kerja, dengan terbukanya kesempatan untuk kenaikan jabatan.

\section{4) Supervisor}

Kemampuan supervisor untuk menyediakan bantuan teknis dan perilaku dukungan. Menurut Locke, hubungan fungsional dan hubungan keseluruhan yang positif memberikan tingkat kepuasan kerja yang paling besar dengan atasan.

\section{5) Rekan Kerja}

Kebutuhan dasar manusia untuk melakukan hubungan social akan terpenuhi dengan adanya rekan kerja yang mendukung karyawan. jika terjadi konflik dengan rekan kerja , maka akan berpengaruh pada tingkat kepuasan karyawan terhadap pekerjaan. 
Ada dua komponen kepuasan kerja (Mas'ud, 2004), yaitu : Pertama, kepuasan intrinsic meliputi variasi tugas, kesempatan berkembang, kesempatan menggunakan kemampuan dan ketrampilan, otonomi, kepercayaan, pekerjaan yang menantang dan bermakna, dsb. Kedua, kepuasan ekstrinsik, meliputi : gaji (upah) yang diperoleh, supervise, jaminan kerja, status dan prestise.

Dimensi tentang kepuasan kerja yang lain juga disampaikan oleh Emilia (2001), yang mengutip dari hasil penelitian Victor S. Desantis dan Samantha L. Durts (1996), yang berjudul Comparing Job Satisfaction Among Public-and Privat-Sector Employees, yang menyatakan bahwa dimensi yang dapat menjelaskan tentang kepuasan kerja adalah :

1) Monetary and nonmonetary reward Financial Reward dan promotion opportunities merupakan variabel yang secara nyata berhubungan dengan kepuasan kerja. selain itu frines benefits seperti waktu untuk berlibur merupakan mekanisme lain untuk memberi kompensasi berdasarkan jasa yang telah diberikan.

2) Job Characteristics

Job characteristics yaitu karyawan yang melakukan tugasnya dengan memiliki sifat-sifat dalam skill variety, job significances, autonomy dan feedback akan menggunakan pengalaman mereka untuk mencapai kepuasan kerja lebih baik dibandingkan dengan karyawan yang tidak menghadapi hal tersebut.

3) Work-environment characteristics

Lingkungan kerja dapat meningkatkan kepuasan kerja yang meliputi : office surroundings and atmosphere.

4) Personal characteristics

Para peneliti mempelajari beberapa atribut karakter seseorang seperti sex, age, race, dan education berhubungan dengan kepuasan kerja.

Harold E. Burt dalam Moh As'ad (2003) menyatakan bahwa factor-faktor yang menyebabkan kepuasan kerja karyawan adalah sebagai berikut :

1) Faktor hubungan antar karyawan 
a. Hubungan antara pimpinan dengan karyawan

b. Factor fisik dan kondisi kerja

c. Hubungan social diantara karyawan

d. Sugesti dari teman sekerja

e. Emosi dari situasi kerja

2) Faktor individu
a. Sikap orang terhadap pekerjaannya
b. Umur orang sewaktu bekerja
c. Jenis kelamin

3) Faktor-faktor Luar
a. Keadaan keluarga karyawan
b. Rekreasi
c. Pendidikan dan training

Robbins (1996) menyatakan bahwa terdapat beberapa variabel yang menentukan kepuaasan kerja. variabel -variabel tersebut adalah sebagai berikut :

1) Kerja yang secara mental menantang

Karyawan lebih menyukai pekerjaan-pekerjaan yang memberikan mereka kesempatan untuk menggunakan ketrampilan dan kemampuan mereka dan menawarkan beragam batas, kebebasan dan umpan balik mengenai betapa baik mereka mengerjakan.

2) Ganjaran yang pantas

Karyawan menginginkan sistem upah dan kebijakan promosi yang mereka persepsikan sebagai adil, tidak kembar arti, dan segaris dengan pengharapan mereka. Bila upah dilihat sebagai adil yang didasarkan pada tuntutan pekerjaan, tingkat ketrampilan individu, dan standar komunikasi, kemungkinan besar akan menghasilkan kepuasan.

3) Kondisi kerja yang mendukung

Karyawan peduli akan lingkungan kerja yang baik untuk kenyamanan pribadi maupun untuk memudahkan mengerjakan tugas yang baik.

4) Rekan pekerja yang mendukung 
Orang-orang mendapatkan lebih daripada sekedar uang atau prestasi yang berwujud dari dalam kerja. Bagi kebanyakan karyawan, kerja juga mengisi kebutuhan akan interaksi social. Rekan kerja yang ramah dan mendukung menghantar kekepuasan kerja yang meningkat.

5) Kesesuaian kepribadian dan pekerjaan

Kecocokan yang tinggi antara kepribadian seseorang akan menghasilkan seorang individu yang lebih terpuaskan.

\subsubsection{Konsukuen Kepuasan Kerja}

Tugas seorang manager sumber daya manusia sangat berkepentingan untuk memahami dan memenuhi berbagai dimensi kepuasan kerja karyawan serta mengantisipasi berbagai kemungkinan konsekuensi terutama yang bernuansa negatif. Menurut Robbins (1996) mengungkapkan dampak kepuasan kerja jika dipenuhi dapat meningkatkan produktifitas, menurunkan abesentisme, menekan perputaran kerja. opsi tindakan pelampiasan ketidakpuasan kerja berupa :

1) Keluar (Exit), ketidakpuasan yang diungkapkan lewat perilaku yang diarahkan untuk meinggalkan organisasi. Mencakup pencairan posisi baru maupun minta berhenti.

2) Suara (Voice), ketidakpuasan yang diungkapkan lewat usaha aktif dan kontruktif untuk memperbaiki kondisi. Mencakup saran perbaikan, membahas masalahmasalah dengan atasan dan beberapa bentuk kegiatan serikat buruh.

3) Kesetiaan (Loyalitas), ketidakpuasan yang diungkapkan dengan secara pasif menunggu membaiknya kondisi. Mencakup berbicara membela organisasi, menghadapi kritik dari luar dan mempercayai organisasi dan manajemen untuk melakukan hal yang tepat.

4) Pengabdian (neglect), ketidakpuasan yang dinyatakan dengan membiarkan kondisi memburuk . termasuk kemangkiran atau datang terlambat secara kronis , upaya yang dikurangi dan tingkat kekeliruan yang meningkat. 
Luthans (2006) mengemukakan bahwa kepuasan kerja berpengaruh terhadap :

1) Kinerja

Karyawan yang tingkat kepuasannya tingi, kinerja akan meningkat, walaupun hasilnya tidak langsung. Ada beberapa variabel moderating yang menghubungkan antara kinerja dengan kepuasan kerja, terutama penghargaan. Jika karyawan menerima penghargaan yang meraka anggap pantas mendapatkannya, dan puas, mungkin ia menghasilkan kinerja yang lebih besar.

2) Pengantian Karyawan

Kepuasan kerja yang tinggi tidak akan membuat pergantian karyawan menjadi rendah, sebaliknya bila terdapat ketidakpuasan kerja , maka pergantian karyawan mungkin akan tinggi.

Menurut Gibson, Ivancevich dan Donnely (1996) dalam Sylvana (2002:4) mengemukakan bahwa kepuasan kerja merupakan bagian dari proses motivasi. Kepuasan kerja dalam organisasi dapat ditunjukkan dengan hasil seperti sikap anggota organisasi, pergantian pekerjaan anggota organisasi, kemangkiran atau absensi, keterlambatan dan keluhan yang biasa terjadi dalam suatu organisasi.

Davis (1985) dalam Mangunegara (2005:117) mengemukakan bahwa :

“ job satisfaction is related to a number of major employee variables, such as turnover, absences, age, occupation, and size of the organization in which an employee works."

Berdasarkan pendapat tersebut, Mangunegara (2005:117) mengemukakan bahwa kepuasan kerja berhubungan dengan variabel-variabel seperti turnover, tingkat absensi, umur, tingkat pekerjaan, dan ukuran organisasi perusahaan.

Kepuasan kerja berhubungan dengan turnover mengandung arti bahwa kepuasan kerja yang tinggi selalu dihubungkan dengan turnover pegawai yang rendah, dan sebaliknya jika pegawai banyak yang merasa tidak puas maka turnover pegawai tinggi. Kepuasan kerja berhubungan dengan tingkat absensi (kehadiran) mengandung arti bahwa pegawai yang kurang puas cenderung tingkat ketidak hadirannya tinggi. Kepuasan kerja berhubungan dengan umur mengandung arti bahwa pegawai yang cenderung lebih tua akan merasa lebih puas daripada pegawai yang berumur relative lebih muda, karena diasumsikan bahwa pegawai yang tua lebih berpengalaman menyesuaikan diri dengan 
lingkungan pekerjaan dan pegawai dengan usia muda biasanya mempunyai harapan yang ideal tentang dunia kerjanya, sehingga apabila antara harapannya dengan realita kerja terdapat kesenjangan atau ketidak-seimbangan dapat menyebabkan mereka menjadi tidak puas.

Kepuasan kerja dihubungkan dengan tingkat pekerjaan mengandung arti bahwa pegawai yang menduduki tingkat pekerjaan yang lebih tinggi cenderung lebih puas daripada pegawai yang menduduki pekerjaan yang lebih rendah, karena pegawai yang tingkat pekerjaannya lebih tinggi menunjukkan kemampuan kerja yang baik dan aktif dalam mengemukakan ide-ide serta kreatif dalam bekerja. Kepuasan kerja berhubungan dengan ukuran organisasi perusahaan mengandung arti bahwa bear kecilnya perusahaan dapat mempengaruhi proses komunikasi, koordinasi, dan partisipasi pegawai sehingga dapat mempengaruhi kepuasan kerja karyawan.

Mangkunegara (2005:120) mengemukakan bahwa ada 2 (dua) factor yang mempengaruhi kepuasan kerja yaitu factor yang ada pada diri pegawai dan factor pekerjannya. Faktor yang ada pada diri pegawai yaitu kecerdasan (IQ), kecakapan khusus, umur, jenis kelamin, kondisi fisik, pendidikan, pengalaman kerja, masa kerja, kepribadian, emosi, cara berpikir, persepsi, dan sikap kerja.

Sedangkan faktor pekerjaan yaitu jenis pekerjaan, struktur organisasi, pangkat (golongan), kedudukan, mutu pengawasan, jaminan keuangan, kesempatan promosi jabatan, interaksi social, dan hubungan kerja.

\subsection{Pengertian Kinerja}

Pengertian kinerja atau performance adalah gambaran mengenai tingkat pencapaian pelaksanaan suatu program kegiatan atau kebijakan dalam mewujudkan sasaran, tujuan, visi, misi organisasi yang dituangkan melalui perencanaan strategi suatu organisasi.

Kinerja merupakan penampilan hasil karya seseorang dalam bentuk kualitas ataupun kuantitas dalam suatu organisasi. Kinerja dapat merupakan penampilan individu maupun kelompok kerja pegawai. Tiga hal penting dalam kinerja adalah tujuan, ukuran, dan penilaian. 
Menurut A. A. Anwar Prabu mangkunegara (2005, h.9) mengatakan bahwa :

“ Kinerja karyawan (prestasi kerja) adalah hasil kerja secara kualitas dan kuantitas yang dicapai oleh seorang karyawan dalam melaksanakan tugasnya sesuai dengan tanggung jawab yang diberikan kepadanya “.

Sedangkan pengertian kinerja pegawai menurut Bambang Kusriyanto (2007, h. 175) yang dikutip oleh Harbani Pasolong dalam bukunya Teori administrasi Publik adalah “ hasil kerja perseorangan dalam suatu organisasi”.

Adapun pengertian kinerja menurut Stephen Robbins (2007, h. 176) yang diterjemahkan oleh Harbani Pasolong " adalah hasil evaluasi tehadap pekerjaan yang dilakukan oleh pegawai dibandingkan kriteria yang telah ditetapkan sebelumnya".

Berdasarkan pengertian kinerja dari beberapa pendapat ahli diatas, dapat ditafsirkan bahwa kinerja pegawai erat kaitannya dengan hasil pekerjaan seseorang dalam suatu organisasi, hasil pekerjaan tersebut dapat menyangkut kualitas, kuantitas, dan ketapatan waktu. Kinerja pegawai tidak hanya dipengaruhi oleh kemampuan dan keahlian dalam bekerja, tetapi juga sangat dipengaruhi oleh semangat kerjanya.

Dimensi-dimensi yang dijadikan ukuran kinerja menurut Nawawi (2000, h. 97) yaitu :

1. Tingkat kemampuan kerja (kompetensi) dalam melaksanakan pekerjaan baik yang diperoleh dari hasil pendidikan dan pelatihan maupun yang bersumber dari pengalaman kerja.

2. Tingkat kemampuan eksekutif dalam memberkan motivasi kerja, agar pekerja sebagai individu bekerja dengan usaha maksimum, yang memungkinkan tercapainya hasil sesuai dengan keinginan dan kebutuhan masyarakat.

Menurut Moeheriono (2009: 61), arti kinerja sebenarnya berasal dari kata job performance dan disebut juga actual performance atau prestasi kerja atau prestasi yang dicapai oleh seorang karyawan.

Dalam Moeheriono (2009:61), menurut Robins bahwa kinerja sebagai fungsi interaksi antara kemampuan atau ability (A), motivation atau motivasi (M) dan kesempatan 
atau opportunity $(\mathrm{O})$, yaitu kinerja $=\mathrm{f}(\mathrm{AxMxO})$; artinya kinerja merupakan fungsi dari kemampuan, motivasi dan kesempatan.

Jadi uraian pendapat Robins tadi jelas bahwa kinerja karyawan akan erat sekali hubungannya dengan kompetensi atau kemampuan yang dimilikinya dan motivasi yang dimiliki oleh karyawan.

Menurut Scriber - Batam English dicronaries dalam Moeheriono , kinerja berasal dari beberapa hal, yaitu :

1. Melakukan, menjalankan, melaksanakan (to do or carry of execute).

2. Memenuhi atau melaksanakan kewajiban suatu niat (to discharge of fulfil of vow).

3. Melaksanakan atau menyempurnakan tanggung jawab (to execute or complete an understaking).

4. Melakukan sesuatu yang diharapkan sesorang atau mesin (to do what is expected of a person or machine).

Menurut Benardin (2001:143), dalam Sudarmanto (2009:8) mengemukakan bahwa :

“ Kinerja merupakan catatan hasil yang di produksi (dihasilkan) atas fungsi pekerjaan tertentu atau aktivitas-aktivitas selama periode waktu tertentu”.

Maksud dari pernyataan diatas bahwa kinerja karyawan adalah sesuatu output yang dihasilkan oleh karyawan dalam lingkungan kerjanya dalam waktu tertentu.

Menurut Murphy (1990:..) dalam Sudarmanto (2009 : 8), menyatakan bahwa kinerja merupakan seperangkat perilaku yang relevan dengan tujuan organisasi tempat orang bekerja.

Pengertian kinerja bukan kontekstual atau hasil tindakan, tetapi tindakan itu sendiri menurut Campbell, 1993, dalam Richard (2003:..).

Di dukung oleh pernyataan A.A Anwar (2008: 67 ), istilah kinerja berasal dari kata Job performance atau actual performance (prestasi kerja atau prestasi yang sesungguhnya dicapai oleh seseorang). Sedanngkan pengertian kinerja (prestasi kerja) 
adalah hasil kerja secara kuantitas dan kualitas yang dicapai oleh seseorang pegawai dalam melaksanakan tugasnya sesuai dengan tanggung jawab yang dberikan padanya.

Sedangkan menurut Mahmudi (2007 : 20’25), kinerja adalah pengetahuan yang mengacu kepada pengetahuan yang dimiliki oleh pegawai (knowing what to do), skill yang mengacu pada kemampuan untuk melakukan pekerjaan (the ability to do well), dan motivasi atau dorongan untuk melakukan kerja.

Di dukung oleh pernyataan Wahyu F Casco "performance refers to an employee's accomplishment of assigned task" (kinerja mengacu pada pegawai yang menyelesaikan dalam tugasnya).

As'ad dalam Agustina (2002) dan Sutiadi (2003:6) mengemukakan bahwa kinerja seseorang merupakan ukuran sejauh mana keberhasilan seseorang dalam melakukan tugas pekerjaannya. Ada 3 (tiga) factor utama yang berpengaruh pada kinerja yaitu :

1) Individu (kemampuan bekerja)

2) Usaha kerja (keinginan untuk bekerja)

3) Dukungan organisasi (kesempatan untuk bekerja)

Menurut Cash dan Fischer (1987) dalam Thoyib (2005:10) mengemukakan bahwa :

"Kinerja sering disebut dengan performance atau result yang diartikan dengan apa yang telah dihasilkan oleh individu karyawan".

Kinerja dipengaruhi oleh kinerja organisasi (organizational performance) itu sendiri yang meliputi pengembangan organisasi (organization development), rencana kompensasi (compensation plan), system komunikasi (communication system), gaya manajerial (manajerial style), struktur organisasi (organization structure), kebijakan dan prosedur (policies and proscedures).

Robbins (2003) dalam Thoyib (2005:10) mengemukakan bahwa istilah lain dari kinerja adalah human output yang dapat diukur dari produktivitas, absensi, turnover, citizenship, dan satisfaction. 
Sedangkan Baron dan Greenberg (1990) dalam Thoyib (2005:10) mengemukakan bahwa kinerja pada individu juga disebut dengan job performance, work outcomes, task performance.

Menurut Brahmasari (2004:64) mengemukakan bahwa :

"Kinerja adalah pencapaian atas tujuan organisasi yang dapat berbentuk output kuantitatif maupun kuallitatif , kreatifitas, fleksibilitas, dapat diandalkan, atau hal-hal lain yang diinginkan oleh organisasi."

Menurut Tika (2006:121) mengemukakan bahwa :

"ada 4 (empat) unsur-unsur yang tedapat dalam kinerja adalah hasil-hasil fungsi pekerjaan, factor-faktor yang berpengaruh terhadap prestasi karyawan, pencapaian tujuan organisasi, dan periode waktu tertentu."

Berdasarkan teori-teori diatas disimpulan bahwa Kinerja Karyawan adalah tindakan kerja atau pelaksanaan tugas yang telah diselesaikan oleh seseorang atau individu dalam kurun waktu tertentu dan dapat diukur dengan penuh rasa tanggung jawab. 


\section{BAB III \\ PEMBAHASAN}

\subsection{Pembahasan dari hasil penelitian}

Berdasarkan analisa statistic meliputi perhitungan koefisien korelasi , koefisien determinasi, uji $\mathrm{F}$ dan regresi. Upaya pendalaman tiap variable dengan menggunakan hasil analisa tersebut yang telah diolah dengan aplikasi SPSS versi 20 dapat diuraikan sebagai berikut :

\subsubsection{Pembahasan Pengaruh Motivasi Kerja $\left(\mathbf{X}_{1}\right)$ dan Kepuasan Kerja $\left(\mathbf{X}_{2}\right)$ terhadap Kinerja Karyawan (Y) secara simultan .}

Nilai $F_{\text {hitung }}$ motivasi kerja dan kepuasan kerja adalah 546,724 dengan tingkat signifikan sebesar 0,000 ( $\mathrm{P}$-value $<0,05$ ), dengan demikian terjadi penolakan $\mathrm{H}_{0}$ yang berarti bahwa menunjukkan adanya pengaruh sangat signifikan antara variable motivasi kerja dan kepuasan kerja secara bersama-sama terhadap kinerja karyawan. Dengan penerapan kedua variable tersebut untuk meningkatkan kinerja karyawan maka kinerja karyawan secara keseluruhan diharapkan dapat meningkat dengan baik.

Dari uraian tersebut jelaslah sudah perusahaan harus lebih memprioritaskan kebutuhan karyawan untuk lebih mengali potensi yang ada pada karyawan, dengan diberikannya Gaji , Bonus, Pelatihan -pelatihan, Promosi jabatan, Tunjangan hari tua, Kesehatan dan rekreasi , maka dengan sendirinya motivasi bekerja akan tibul dengan sendirinya tanpa adanya paksaan dan karyawan akan terpuaskan .

\subsubsection{Pembahasan Pengaruh Motivasi Kerja ( $\left.\mathrm{X}_{1}\right)$ terhadap kinerja Karyawan (Y)} secara Parsial.

Nilai $\mathrm{T}_{\text {hitung }}$ motivasi kerja $\left(\mathrm{X}_{1}\right)$ sebesr 25,865 dengan tingkat signifikan sebesar 0,000 (P-value < 0,05) dengan demikian terjadi penolakan $\mathrm{H}_{0}$ yang berarti bahwa adanya pengaruh sangat signifikan antara variable motivasi kerja $\left(\mathrm{X}_{1}\right)$ terhadap variable kinerja karyawan (Y). Motivasi kerja ini pengaruhnya sangat signifikan terhadap kinerja karyawan, sehingga motivasi kerja perlu dipertahankan dan dijaga agar kinerja karyawan tetap berada pada kondisi yang baik.

Motivasi akan mendorong setiap karyawan untuk lebih bekerja lebih baik, disiplin, karena perusahaan harus berupaya keras untuk mendorong dan memotivasi 
karyawannya dengan Perlakuan yang adil, Promosi , kenyaman dalam bekerja, suasana dan iklim bekerja kondusif.

\subsubsection{Pembahasan Pengaruh Kepuasan kerja $\left(\mathbf{X}_{2}\right)$ terhadap Kinerja Karyawan} (Y) secara Parsial.

Nilai $\mathrm{T}_{\text {hitung }}$ kepuasan kerja $\left(\mathrm{X}_{2}\right)$ sebesar 12,533 dengan tingkat signifikan sebesar 0,000 (P-value < 0,05) dengan demikian terjadi penolakan $\mathrm{H} 0$ yang berarti bahwa menunjukkan adanya pengaruh sangat signifikan antara variable kepuasan kerja $\left(\mathrm{X}_{2}\right)$ terhadap variable kinerja karyawan $(\mathrm{Y})$. kepuasan kerja ini pengaruhnya sangat besar terhadap kinerja karyawan, sehingga kepuasan kerja perlu dipertahankan dan dijaga agar kinerja karyawan tetap terjaga pada kondisi yang baik.

Kepuasan karyawan bisa dirasakan dengan pemberian bonus, insentif, perlakuaan yang adil, kesehatan terjamin, dll. Rasa aman dalam bekerja itu juga merupakan dampak psikologis yang bisa berdampak pada kepuasan karyawan. Promosi yang sering ditunda-tunda bisa membuat karyawan merasa tidak diperhatikan oleh perusahaan dan akan berpengaruh terhadap kinerja karyawan itu sendiri dan dapat merugikan perusahaan. 


\section{BAB IV}

\section{KESIMPULAN DAN SARAN}

\subsection{Kesimpulan}

Kesimpulan dari penelitian mengenai pengaruh motivasi dan kepuasan kerja terhadap kinerja karyawan di PT. Bank Negara Indonesia (Persero)Tbk Kantor Cabang Karawang yaitu :

4.1.1 Motivasi kerja dan kepuasan kerja secara bersama-sama berpengaruh sangat signifikan terhadap kinerja karyawan d PT. Bank Negara Indonesia (Persero)Tbk Kantor Cabang Karawang. Keadaan ini ditunjukan dari nilai uji F, dimana nilai Sig. F lebih kecil dari $\alpha$ yang berarti bahwa motivasi dan kepuasan kerja bersama-sama berpengaruh terhadap kinerja karyawan di PT. Bank Negara Indonesia (Persero)Tbk Kantor Cabang Karawang.

4.1.2 Motivasi kerja berpengaruh sangat signifikan terhadap kinerja karyawan di PT. Bank Negara Indonesia (Persero)Tbk Kantor Cabang Karawang. Keadaan ini ditunjukan dari nilai uji $\mathrm{T}$, dimana nilai Sig.T lebih besar dari nilai $\alpha$ yang berarti bahwa motivasi kerja berpengaruh sangat signifikan terhadap kinerja karyawan di PT. Bank Negara Indonesia (Persero)Tbk Kantor Cabang Karawang.

4.1.3 Kepuasan kerja berpengaruh sanagt signifikan terhadap kinerja karyawan di PT. Bank Negara Indonesia (Persero)Tbk Kantor Cabang Karawang. Keadaan ini ditunjukkan dari niai uji t, dimana nilai Sig. $t$ lebih besar dari nilai $\alpha$ yang berate bahwa kepuasan berpengaruh sangat signifikan terhadap kinerja karyawan di PT. Bank Negara Indonesia (Persero)Tbk Kantor Cabang Karawang 


\subsection{Saran}

Saran-saran yang dapat diberikan dari hasil penelitian ini yaitu :

4.2.1 Perlu dipertahankannya motivasi kerja yang ada di PT. Bank Negara Indonesia (Persero)Tbk Kantor Cabang Karawang agar kondisi kinerja karyawan dapat tetap terjaga pada kondisi yang baik.

4.2.2 Perlu dipertahankannya kondisi kepuasan kerja karyawan kearah yang lebih baik pada PT. Bank Negara Indonesia (Persero)Tbk Kantor Cabang Karawang agar kondisi kinerja karyawan dapat tetap terjaga pada kondisi yang lebih baik.

4.2.3 Perlu adanya pelatihan- pelatihan untuk meningkatkan sumber daya manusia yang lebih baik dan berkeativitas tinggi sehingga karyawan lebih termotivasi untuk bekerja dengan baik.

4.2.4 Promosi jabatan harus bergulir disetiap kesempatan untuk memberikan karyawan lebih memberikan kinerja yang lebih baik dan mengukur kemampuan atau skill yang di miliki oleh karyawan 


\section{DAFTAR PUSTAKA}

Augustry Ferdinand, 2006. Metode Penelitian Manajemen. Semarang : Badan Penerbit Universitas Diponegoro.

Brahmasari Ida Ayu, 2004. Pengaruh Variabel Budaya Perusahaan terhadap Komitmen Karyawan dan KInerja Perusahaan Kelompok Penerbit Pers Jawa Pos, DIsertasi Universitas Airlangga.

Budiman Fransiska Maria, 2005. Pengaruh Waiabel Budaya Perusahaan terhadap KInerja Perusahaan suatu Studi pada Plaza Marina Surabaya, Tesis Universitas 17 Agustus, Surabaya.

Damanhuri Didin S., 2003. SDM Indonesia Dalam Persaingan Global , Jurnal Harian Sinar Harapan, Bogor.

Dewi Ma'rifah, 2006. Pengaruh Motivasi Kerja dan Budaya Organisasi terhadap Kinerja Pekerja Sosial pada Unit Pelaksana Teknis Dinas Sosial Propinsi Jawa Barat, http://.damanhuri.or.id.diakses tanggal 1 maret 2010.

Galih Pramon, 2004. Analisis Pengaruh Ketidakamanan Kerja terhadap Kepuasan Kerja dengan Variabel Moderator Umur dan Laman Kerja (Studi Kasus Pada Karyawan Bagian Pemasaran PT. Batik Danarhadi Surakarta. Skripsi dipublikasikan. www.digilib.uns.ac.id, diakses tanggal 09 November 2010.

Hani T Handoko, 1996. Manajemen Personalia dan Sumber Daya Manusia. Edisi 2. Yogyakarta : BPFE.

Heidi Rachman Ranupandojo dan Suad Husnan, 2002. Manajemen Personalia. Yogyakarta : BPFE.

Kreitner, Robert dan Angelo Kinicki, 2005. Perilaku Organisasi. Jakarta : Salemba Empat Luthans, Fred, 2006, Perilaku Organisasi 10 . Edisi Indonesia. Yogyakarta : Penerbit ANDI. Malayu SP Hasibuan, 2003, Manajemen Sumber Daya Manusia, Yogyakarta : STIE YKPN Mangkunegara Anwar Prabu, 2005. Manajemen Sumber Daya Manusia Perusahaan, cetakan keenam, PT. Remaja Rosdakarya, Bandung.

Moch As'ad, 2003. Psikologi Industri. Yogyakarta : Liberty.

M. Manullang, 1981 . Manajemen Personalia, Jakarta Ghalia Indonesia

Netania Emilisa, 2001. Hubungan Antara Job Satisfaction dengan Organizational Commitment pada Dana Pensiun Lembaga Keuangan yang dikelola oleh 
Perusahaan Asuransi di Jakarta. Jurnal Media Riset Bisnis \& Manajemen. Vol. 1 No. 3. Pp.229-244.

Nuzsep Almigo, 2004. Hubungan anatara Kepuasan kerja dengan Produktivitas Kerja Karyawan . Jurnal PSYCHE. Vo. 1, No. 1, Desember 2004. 